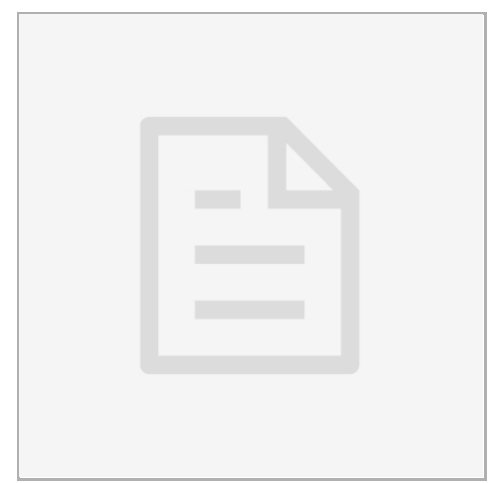

VERSION 3

MAY 20, 2020

\section{open $\partial$ ACCESS}

\section{DOI:}

dx.doi.org/10.17504/protocol s.io.bgpvjvn6

\section{Protocol Citation: Allen} Institute for Brain Science 2020. Stereotaxic Surgery for Delivery of Tracers by lontophoresis. protocols.io https://dx.doi.org/10.17504/p rotocols. io.bgpvjvn6

License: This is an open access protocol distributed under the terms of the Creative Commons Attribution License, which permits unrestricted use, distribution, and reproduction in any medium, provided the original author and source are credited

Protocol status: Working We use this protocol and it's working

Created: May 20, 2020

Last Modified: Mar 16, 2021

\section{PROTOCOL integer ID:}

\section{3}

Keywords: AF0092, surgery, tracers, injection, iontophoresis

\title{
(3) Stereotaxic Surgery for Delivery of Tracers by Iontophoresis V.3
}

\section{Allen Institute for Brain Science ${ }^{1}$}

\section{${ }^{1}$ Allen Institute}

\section{BICCN Allen Institute for Brain Science}<smiles>C1CCCCCC1</smiles>

Allen Institute

\section{ABSTRACT}

This protocol describes the delivery of a neuronal tracer using the iontophoretic method. The surgery uses a stereotaxic system to target specific brain coordinates in the mouse.

Note: Research reported in this publication was supported by the National Institute Of Mental Health of the National Institutes of Health under Award Number U19MH114830. The content is solely the responsibility of the authors and does not necessarily represent the official views of the National Institutes of Health.

\section{ATTACHMENTS \\ Standard of Care Protocol.xlsx \\ NSBWI- \\ 0022_all_procedures_setu p_take_down.docx \\ AF0092_Stereotaxic_Surg \\ ery_for_Delivery_of_Trace \\ rs_by_lontophoresis.docx}


